\title{
CHEMICAL COMPOSITION OF WINTER TRITICALE GRAIN DEPENDING ON TYPE OF TILLAGE IN CROP ROTATION
}

\author{
Boguslawa Jaskiewicz \\ Institute of Soil Science and Plant Cultivation State Research Institute in Pulawy, Poland \\ kos@iung.pulawy.pl
}

\begin{abstract}
Triticale is a fodder cereal with a high nutritional value of grains. It can also be used for food purposes, so the chemical composition of the grain is important. The aim of the study was to determine the changes in the macroelement content in the grains of winter triticale cultivars under the use of different tillage methods and the percentage of cereals in the crop rotation. The research shows that the chemical composition of grains depends on the weather conditions, tillage method, and the share of cereals in crop rotation, as well as the genetic factor. In the year of the study, with the highest precipitation in the growing period, the highest concentrations of magnesium and phosphorus were found. The accumulation of nitrogen and sodium in triticale grain was higher in the year with lower precipitation. In crop rotation with a lower percentage of cereals, higher concentrations of nitrogen, potassium, phosphorus, and calcium were found. The concentrations of nitrogen, phosphorus and magnesium did not depend on the method of soil tillage, whereas in ploughing conditions, higher concentrations of potassium, calcium and sodium were found. Alekto cultivar was characterized by a higher content of macroelements (nitrogen and sodium) in the grains, while Fredro cultivar, of calcium. The content of phosphorus in grain was similar in Alekto and Cerber cultivars.
\end{abstract}

Keywords: macroelements, cultivars, tillage, triticale, crop rotation.

\section{Introduction}

Triticale is a cereal of high economic importance. According to FAOSTAT [1], 15.6 million tons of triticale grains were harvested in 41 countries around the world in 2017. In Poland, 5.3 million tons of triticale grains were harvested in 2017. Triticale grain has a high nutritional value and is mainly used for feed purposes [2-4]. The use of triticale grain for food purposes is still being researched [5-7]. Therefore, the level of mineral components in triticale grain is important, as the unfavorable level may cause a decrease in the biological value of feed and adversely affect the metabolism of animals [8;9]. Earlier studies $[4 ; 10-13]$ show that the quality of triticale grains depends on the genetic, agro technical and environmental factors. Research by Jaskiewicz [14], and Jaskiewicz et al. [10] indicates that the yields of winter triticale cultivars depend on the tillage method and the percentage of cereals in the sowing structure.

It is assumed that plough tillage and crop rotation with a lower percentage of cereals in the sowing structure allow obtaining winter triticale grains with a higher content of macro elements.

The aim of the study was to determine the changes in the macro element content in the grains of winter triticale cultivars under the use of different tillage methods and different percentage of cereals in crop rotation.

\section{Materials and Methods}

The studies were conducted in the years of 2012/2013, 2014-2016 in the ES of the Institute of Soil Science and Plant Cultivation State Research Institute in Pulawy, Poland. The study was carried out on an area of $45 \mathrm{~m}^{2}$ in four replications on soil with $1.81 \mathrm{mg} \mathrm{K}, 1.73 \mathrm{mg} \mathrm{P}$, and neutral reaction (pH KCL 6.5). Triticale sowing took place on 25 September. Triticale was cultivated in field experiments existing for over twenty years, in cereal monoculture (after winter wheat) and in crop rotation with $75 \%$ share of cereals in crop rotation (after rape). The first research factor is the method of tillage (ploughing or simplified). In plough cultivation, after harvesting the fore crop, straw was crushed, and then subsoiling, harrowing, and pre-sowing ploughing were carried out. On the other hand, in simplified tillage, after straw crushing, the soil was tilled with a cultivator.

The second factor was the long-straw winter triticale cultivars: Cerber, Fredro as well as a semidwarf cultivar Alekto. The amount of seeds sown was 3.5 million seeds per hectare.

In the years 2012/2013, the average air temperature was close to the long-term mean, while the other two growing seasons were characterized by higher temperatures. Nevertheless, a more optimal layout of temperatures and precipitation was recorded in 2016. The course of weather conditions has been described in detail in the scientific study by Jaskiewicz et al. [10]. 
Chemical analyses of macro elements content $(\mathrm{N}, \mathrm{P}, \mathrm{K}, \mathrm{Mg}, \mathrm{Ca}$ and $\mathrm{Na})$ in grain samples taken during the harvest were performed in GLACH IUNG-PIB in Puławy, Poland. The contents of nitrogen and phosphorus were determined with the flow analysis method, according to PB 33.1- second edition05.03.2014. The contents of potassium, magnesium, calcium, and sodium were determined with the FAES method, according to PB 32.1 - second edition - 08.03.2014.

The obtained results were statistically worked out in the software Statistic, with the method of the analysis of variance ANOVA, and the differences were estimated with the Tukey's test at $\alpha=0.05$.

\section{Results and Discussion}

The percentage of cereals in the sowing structure, tillage method, and the genetic factor differentiated the chemical composition of winter triticale grains in the years of the study. Nitrogen concentration in grains in 2016 was found to be by $15 \%$ and $18 \%$ higher than in the other two years (Table 1). Total precipitation in the growing season of 2015/2016 was lower and had a higher average air temperature compared to the long-term average [10]. Sodium concentration in triticale grains was similar to the nitrogen concentration (Table 3). In 2013 the sodium concentration in the grains was by $14 \%$ lower than in 2016, while in 2015 its concentration decreased more than twice.

The concentrations of phosphorus and magnesium in grain showed different tendencies (Table 1,2). Their highest concentrations were found in the year (2013) with much higher precipitation compared to the long-term average [10]. According to Bielski [15], plants accumulate phosphorus in their grains better under favorable humidity conditions.

Table 1

Nitrogen and phosphorus concentrations in triticale grains, $\mathrm{g} \mathrm{kg}^{-1}$ of dry matter

\begin{tabular}{|c|c|c|c|c|c|c|c|c|}
\hline \multirow{2}{*}{ Treatment } & \multicolumn{9}{|c|}{ N } & \multicolumn{3}{|c|}{ P } \\
\cline { 2 - 9 } & $\mathbf{2 0 1 3}^{1}$ & $\mathbf{2 0 1 5}$ & $\mathbf{2 0 1 6}$ & Mean & $\mathbf{2 0 1 3}^{1}$ & $\mathbf{2 0 1 5}$ & $\mathbf{2 0 1 6}$ & Mean \\
\hline${ }^{2} 100 \%$ & $18.6 \mathrm{~b}$ & $19.1 \mathrm{~b}$ & $22.0 \mathrm{~b}$ & $19.9 \mathrm{~b}$ & $3.59 \mathrm{~b}$ & $3.02 \mathrm{~b}$ & $2.72 \mathrm{~b}$ & $3.11 \mathrm{~b}$ \\
$75 \%$ & $19.9 \mathrm{a}$ & $20.6 \mathrm{a}$ & $23.5 \mathrm{a}$ & $21.3 \mathrm{a}$ & $3.64 \mathrm{a}$ & $3.10 \mathrm{a}$ & $3.09 \mathrm{a}$ & $3.26 \mathrm{a}$ \\
\hline${ }^{3}$ Tillage & $19.5 \mathrm{a}$ & $19.8 \mathrm{a}$ & $22.4 \mathrm{a}$ & $20.6 \mathrm{a}$ & $3.66 \mathrm{a}$ & $3.04 \mathrm{a}$ & $2.95 \mathrm{a}$ & $3.22 \mathrm{a}$ \\
Reduced & $18.9 \mathrm{a}$ & $19.7 \mathrm{a}$ & $23.1 \mathrm{~b}$ & $20.6 \mathrm{a}$ & $3.58 \mathrm{a}$ & $3.09 \mathrm{a}$ & $2.85 \mathrm{a}$ & $3.17 \mathrm{a}$ \\
\hline${ }^{4}$ Alekto & $19.7 \mathrm{a}$ & $20.7 \mathrm{a}$ & $23.9 \mathrm{a}$ & $21.4 \mathrm{a}$ & $3.61 \mathrm{~b}$ & $3.17 \mathrm{a}$ & $2.96 \mathrm{a}$ & $3.25 \mathrm{a}$ \\
Cerber & $19.0 \mathrm{a}$ & $19.4 \mathrm{~b}$ & $22.1 \mathrm{~b}$ & $20.2 \mathrm{~b}$ & $3.77 \mathrm{a}$ & $3.25 \mathrm{a}$ & $2.96 \mathrm{a}$ & $3.33 \mathrm{a}$ \\
Fredro & $19.2 \mathrm{a}$ & $19.1 \mathrm{~b}$ & $22.4 \mathrm{~b}$ & $20.2 \mathrm{~b}$ & $3.48 \mathrm{c}$ & $2.79 \mathrm{~b}$ & $2.74 \mathrm{~b}$ & $3.00 \mathrm{~b}$ \\
\hline Mean & $19.3 \mathrm{~b}$ & $19.7 \mathrm{~b}$ & $22.8 \mathrm{a}$ & 20.6 & $3.62 \mathrm{a}$ & $3.06 \mathrm{~b}$ & $2.88 \mathrm{c}$ & 3.19 \\
\hline
\end{tabular}

${ }^{1}$ year of harvest, ${ }^{2}$ crop rotation, ${ }^{3}$ tillage method, ${ }^{4}$ cultivars

$\mathrm{a}, \mathrm{b}, \mathrm{c}-$ correlation coefficients are significant $p \leq 0.05$

Table 2

Potassium and magnesium concentrations in triticale grains, $\mathrm{g} \mathrm{kg}^{-1}$ of dry matter

\begin{tabular}{|c|c|c|c|c|c|c|c|c|}
\hline \multirow{2}{*}{ Treatment } & \multicolumn{9}{|c|}{ K } & \multicolumn{4}{|c|}{ Mg } \\
\cline { 2 - 9 } & $\mathbf{2 0 1 3}^{1}$ & $\mathbf{2 0 1 5}$ & $\mathbf{2 0 1 6}$ & Mean & $\mathbf{2 0 1 3}^{1}$ & $\mathbf{2 0 1 5}$ & $\mathbf{2 0 1 6}$ & Mean \\
\hline${ }^{2} 100 \%$ & $5.02 \mathrm{~b}$ & $5.66 \mathrm{~b}$ & $4.98 \mathrm{~b}$ & $5.22 \mathrm{~b}$ & $1.20 \mathrm{a}$ & $1.10 \mathrm{~b}$ & $1.12 \mathrm{a}$ & $1.14 \mathrm{a}$ \\
$75 \%$ & $5.21 \mathrm{a}$ & $5.87 \mathrm{a}$ & $5.15 \mathrm{a}$ & $5.41 \mathrm{a}$ & $1.21 \mathrm{a}$ & $1.21 \mathrm{a}$ & $1.14 \mathrm{a}$ & $1.19 \mathrm{a}$ \\
\hline${ }^{3}$ Tillage & $5.21 \mathrm{a}$ & $5.74 \mathrm{a}$ & $5.12 \mathrm{a}$ & $5.36 \mathrm{a}$ & $1.20 \mathrm{a}$ & $1.14 \mathrm{a}$ & $1.11 \mathrm{a}$ & $1.15 \mathrm{a}$ \\
Reduced & $5.01 \mathrm{~b} \mathrm{a}$ & $5.79 \mathrm{a}$ & $5.01 \mathrm{~b}$ & $5,27 \mathrm{~b}$ & $1.20 \mathrm{a}$ & $1.16 \mathrm{a}$ & $1.13 \mathrm{a}$ & $1.16 \mathrm{a}$ \\
\hline${ }^{4}$ Alekto & $5.29 \mathrm{a}$ & $6.01 \mathrm{a}$ & $5.23 \mathrm{a}$ & $5.51 \mathrm{a}$ & $1.21 \mathrm{a}$ & $1.20 \mathrm{a}$ & $1.17 \mathrm{a}$ & $1.19 \mathrm{a}$ \\
Cerber & $5.30 \mathrm{a}$ & $5.81 \mathrm{~b}$ & $5.10 \mathrm{~b}$ & $5.40 \mathrm{~b}$ & $1.21 \mathrm{a}$ & $1.17 \mathrm{a}$ & $1.16 \mathrm{a}$ & $1.18 \mathrm{a}$ \\
Fredro & $4.75 \mathrm{~b}$ & $5.51 \mathrm{c}$ & $4.88 \mathrm{c}$ & $5.04 \mathrm{c}$ & $1.20 \mathrm{a}$ & $1.10 \mathrm{a}$ & $1.06 \mathrm{a}$ & $1.12 \mathrm{a}$ \\
\hline Mean & $5.11 \mathrm{~b}$ & $5.78 \mathrm{a}$ & $5.07 \mathrm{~b}$ & 5.32 & $1.21 \mathrm{a}$ & $1.16 \mathrm{ab}$ & $1.13 \mathrm{~b}$ & 1.16 \\
\hline
\end{tabular}

${ }^{1}$ see Table 1

The weather conditions in 2016 negatively affected the concentration of magnesium in triticale grains (Table 2). Its concentration decreased by $7 \%$ compared to 2013. On the other hand, the year 2015, which saw an average air temperature in April, May, and June at the level of long-term mean, but slightly warmer March and July, had a positive effect on the accumulation of potassium and calcium in the grains (Table 2, 3). The 2014/2015 growing season was characterized by $25 \%$ lower 
precipitation compared to the long-term average [10]. In the harvest year 2015, a 13-14\% increase in the potassium concentration in the grains and a $22 \%$ and $75 \%$ increase in calcium compared to 2016 and 2013, respectively, were recorded (Table 2, 3).

Table 3

Calcium and sodium concentrations in triticale grains, $\mathrm{gkg}^{-1}$ of dry matter

\begin{tabular}{|l|l|l|l|l|l|l|l|l|}
\hline \multirow{2}{*}{ Treatment } & \multicolumn{9}{|c|}{ Ca } & \multicolumn{4}{|c|}{ Na } \\
\cline { 2 - 9 } & $\mathbf{2 0 1 3}^{1}$ & $\mathbf{2 0 1 5}$ & $\mathbf{2 0 1 6}$ & Mean & $\mathbf{2 0 1 3}^{\mathbf{1}}$ & $\mathbf{2 0 1 5}$ & $\mathbf{2 0 1 6}$ & Mean \\
\hline${ }^{2} 100 \%$ & $0.410 \mathrm{~b}$ & $0.743 \mathrm{~b}$ & $0.608 \mathrm{~b}$ & $0.587 \mathrm{~b}$ & $0.046 \mathrm{~b}$ & $0.023 \mathrm{a}$ & $0.064 \mathrm{~b}$ & $0.044 \mathrm{~b}$ \\
$75 \%$ & $0.448 \mathrm{a}$ & $0.758 \mathrm{a}$ & $0.623 \mathrm{a}$ & $0.610 \mathrm{a}$ & $0.063 \mathrm{a}$ & $0.039 \mathrm{a}$ & $0.084 \mathrm{a}$ & $0.062 \mathrm{a}$ \\
\hline${ }^{3}$ Tillage & $0.441 \mathrm{a}$ & $0.758 \mathrm{a}$ & $0.622 \mathrm{a}$ & $0.607 \mathrm{a}$ & $0.059 \mathrm{a}$ & $0.039 \mathrm{a}$ & $0.080 \mathrm{a}$ & $0.059 \mathrm{a}$ \\
Reduced & $0.418 \mathrm{~b}$ & $0.744 \mathrm{~b}$ & $0.608 \mathrm{~b}$ & $0.590 \mathrm{~b}$ & $0.053 \mathrm{a}$ & $0.022 \mathrm{~b}$ & $0.068 \mathrm{~b}$ & $0.048 \mathrm{~b}$ \\
\hline${ }^{4}$ Alekto & $0.424 \mathrm{~b}$ & $0.747 \mathrm{~b}$ & $0.601 \mathrm{~b}$ & $0.590 \mathrm{~b}$ & $0.055 \mathrm{a}$ & $0.035 \mathrm{a}$ & $0.085 \mathrm{a}$ & $0.058 \mathrm{a}$ \\
Cerber & $0.413 \mathrm{c}$ & $0.740 \mathrm{~b}$ & $0.574 \mathrm{c}$ & $0.576 \mathrm{c}$ & $0.054 \mathrm{a}$ & $0.028 \mathrm{a}$ & $0.073 \mathrm{~b}$ & $0.051 \mathrm{a}$ \\
Fredro & $0.455 \mathrm{a}$ & $0.764 \mathrm{a}$ & $0.674 \mathrm{a}$ & $0.631 \mathrm{a}$ & $0.051 \mathrm{a}$ & $0.027 \mathrm{a}$ & $0.063 \mathrm{c}$ & $0.047 \mathrm{~b}$ \\
\hline Mean & $0.431 \mathrm{c}$ & $0.752 \mathrm{a}$ & $0.614 \mathrm{~b}$ & 0.599 & $0.053 \mathrm{~b}$ & $0.030 \mathrm{c}$ & $0.073 \mathrm{a}$ & 0.052 \\
\hline
\end{tabular}

${ }^{1}$ See Table 1

Under $75 \%$ share of cereals in the structure of sowing triticale plants have more favorable conditions of growth and development, agro phages occur in lower amounts, and soil conditions are more favorable than in cereal monoculture [16]. In our own studies, under crop rotation with a lower percentage of cereals, higher concentrations of nitrogen, phosphorus, and potassium in the grains, as compared to cereal monoculture, were noted in each analyzed harvest year (Table 1,2). The content of some macroelements depended on the year of harvest and the percentage of cereals in crop rotation. In 2013 the magnesium concentration, and in 2015 the calcium and sodium concentrations did not depend on crop rotation (Table 2).

The analyzed methods of tillage did not significantly differentiate the concentration of phosphorus, magnesium (Table 1,2). The concentrations of nitrogen, potassium, calcium, and sodium in triticale grain depended on the harvest year (Table 1, 2, 3). In 2016, higher concentrations of nitrogen, potassium and sodium were found in plough cultivation conditions. In the same growing conditions, the accumulation of sodium was also high in the harvest year 2015. The calcium concentration in the grains, regardless of the harvest year, was significantly higher in plough cultivation compared to the simplified one. In the studies of Lyson and Biel [17], the tillage method did not differentiate the concentration of mineral components in triticale grains, while the genetic factor had a significant influence only on the concentrations of phosphorus and potassium.

In earlier studies [4], the protein concentration in the grains was similar in both tillage methods. In our study, regardless of the year of harvest, the average nitrogen concentration in the grains was also similar in both cultivation methods (Table 1).

The influence of the cultivar on the macro element content in triticale grains was found. Alekto cultivar was characterized by the highest nitrogen content in the grains (Table 1). In other cultivars, the content of this macro element was similar. Significantly lower concentration of phosphorus was noted for Fredro cultivar. In studies by Knapowski et al. [18], Kargo cultivar had a higher concentration of phosphorus in the grains, i.e. $4.15 \mathrm{~g} \mathrm{~kg}^{-1}$, as compared to the analyzed cultivars in own studies. However, compared to the results of Knapowski et al. [18], the analyzed triticale had a higher potassium concentration in the grain. In our study the lowest potassium concentration in the grains was found for Fredro cultivar, while the highest for Alekto (Table 2). Also, in the studies by Scigalska et al. [19], the total potassium concentration in triticale grain depended on the genetic factor.

Magnesium concentration in triticale grains did not depend on the cultivar (Table 2). In the Brzozowska study [20], the magnesium concentration in the grains of the Bogo cultivar ranged from 1.2 to $1.5 \mathrm{~g} \mathrm{~kg}^{-1}$ of dry matter. In our study, this value was lower $\left(1.16 \mathrm{~g} \mathrm{~kg}^{-1}\right.$ of dry matter on average). Makarska et al. [21] obtained a slightly higher concentration of magnesium in triticale grains.

Fredro cultivar had $10 \%$ higher calcium content than Cerber cultivar (Table 3). Similar calcium concentration in triticale grains was obtained by Brzozowska [20], while lower by Makarska et al. [21] and Knapowski et al. [13]. The concentration of calcium in the grains depends on the growing 
conditions, the cultivar, as well as the sodium concentration. In the cultivars Alekto and Cerber, significantly higher concentration was found, while in cultivar Fredro - lower $\left(0.047 \mathrm{~g} \mathrm{~kg}^{-1}\right.$ of dry matter). The average concentration of this component was lower than the values obtained in their studies [21], which range from 0.134 to $0.254 \mathrm{~g} \mathrm{~kg}^{-1}$ of dry matter.

\section{Conclusions}

1. The concentrations of nitrogen, phosphorus and magnesium did not depend on the method of soil tillage, whereas in ploughing conditions higher concentrations of potassium, calcium and sodium were found.

2. In crop rotation with a lower percentage of cereals, higher concentrations of nitrogen, potassium, phosphorus and calcium were found.

3. Alekto cultivar had a higher content of nitrogen and sodium in the grains, while Fredro cultivar of calcium. The concentration of phosphorus in the grains was similar in Alekto and Cerber cultivars.

4. Weather conditions in the years of the study significantly influenced the concentration of macroelements in winter triticale grains. In the year of the study, with the highest precipitation in the growing season, the highest concentrations of magnesium and phosphorus were found. The accumulation of nitrogen and sodium in triticale grain was higher in the year with lower precipitation.

5. The fodder and consumption value of grains can be improved by shaping the chemical composition of grains, sowing a high-quality cultivar, applying the plough tillage method, or reducing the percentage of cereals in crop rotation.

\section{References}

[1] [FAOSTAT]. FAO Statistics Division. 2019. [online][16.02.2019] Available at: http://faostat. fao.org.

[2] Coffey M.T., Gerrits W.J. Digestibility and feeding value of B858 triticale for swine. Journal Animal Science, Vol. 66, 2009, pp. 2728-2735.

[3] Djekic V., Mitrovic S., Milovanovic M., Djuric N., Kresovic B., Tapanarova A., Djermanovic, Mitrovic M. Implementation of triticale in nutrition of non-ruminant animals. African Journal of Biotechnology, vol.10(30), 2011, pp. 5697-5704.

[4] Jaskiewicz B., Szczepanek M. Crop management and variety have influence on alkylresolcinol content in triticale grain. Acta Agriculturae Scandinavica, Section B- Soil Plant Science, vol. 66 (7), 2016, pp. 570-574. doi.org/10.1080/09064710.2016.1201139

[5] McGoverin c.m, Snyders F., Muller N., Botes W., Fox G., Manley M. A review of triticale uses and the effect of growth environment on grain quality. Journal of the Science of Food and Agriculture, vol. 91, 2011, pp. 1155-1165.

[6] Nezami A., Soleimani M.R., Ziaee M., Ghodsi M., Aval M.B. Evaluation of freezing tolerance of hexaploid triticale genotypes under controlled conditions. Notulae Scientia Biologicae, vol. 2(2), 2010, pp.114-120.

[7] Tohver M., Kann A., Täht R., Mihhalevski A., Hakman J. Quality of triticale cultivars suitable for growing and bread-making in northern conditions. Food Chemistry, vol. 89, 2005, pp.125-132.

[8] Brzóska F., Śliwiński B. Jakość pasz objętościowych w żywieniu przeżuwaczy i metody jej oceny. (Quality of roughages in ruminant nutrition and methods for its evaluation). Wiadomości Zootechniczne, vol. 2, 2011. pp.11-23.(In Polish).

[9] Fridrich M., Podlaszewska G. Ocena wpływu uzupełniania paszy wybranymi składnikami mineralnymi na ich metabolizm i dystrybucję w organizmie _ badania modelowe. (Assessing effects of suplementing fodder with selected mineral components on their metabolism and distribution in body-model research). Żywność. Nauka. Technologia. Jakość. vol. 1 (98), 2015, pp. 207-219. (In Polish). DOI: 10.15193/zntj/2015/98/016

[10] Jaskiewicz B., Grabinski J., Ochmian I. Productivity of winter triticale depending on type of tillage in crop rotation. Proceedings of 17th International Scientific Conference „Engineering for Rural Development”, Jelgava, Latvia,[accessed 23-24.05. 2018], p. 491-496 Available at: doi: 10.22616/ERDev2018.17.N075 
[11]Jaskiewicz B., Szczepanek M. Amino acids content in Triticale grain depending on meteorological, agrotechnicaland genetic factors. Latvia University of Life Sciences and Technologies, Proceedings of 24 th International Scientific Conference, Jelgava, vol. 2, 2018, pp.28_35. Available at: http://www2.1lu.lv/research_conf/proceedings.htm

[12] Kozak M, Samborski S, Rozbicki J, Mądry W. Winter triticale grain yield, a comparative study of 15 genotypes. Acta Agriculturae Scandinavica, Section B- Soil Plant Science, vol. 57, 2007, pp. 263-270.

[13] Mut Z., Sezer I., Gülümser A. Effect of different sowingrates and nitrogen levels on grain yield, yield components and some quality trains of triticale. Asian Journal of Plant Sciences, vol. 4, 2005, pp. 533-539

[14] Jaskiewicz B. Wpływ technologii produkcji na plonowanie pszenżyta ozimego w warunkach różnego udziału zbóż w strukturze zasiewów. (The impact of production technology on yields of winter triticale under varied percentages of cereals to total cropped area). Polish Journal of Agronomy, vol. 23, 2015, pp.11-17. (In Polish).

[15] Bielski S. Influence of nitrogen fertilization and fungicide protection on macroelements content in winter triticale grain. Annales UMCS, Sec. E. Agricultura, LXX(4), 2015. pp. 1-11.(in Polish)

[16] Smagacz J., Kuś J. Wpływ długotrwałego stosowania płodozmianów zbożowych na plonowanie zbóż oraz wybrane chemiczne właściwości gleby. (Influence of cereal crop rotation on yielding of cereals and selected chemical soil properties). Fragmenta. Agronomica, vol. 27(4), 2010, pp.119-134.(In Polish).

[17]Lyson E., Biel W. The effect of the cultivation system of selected winter triticale grain (x Triticosecale Witm.ex A. Camus). Annales UMCS, Agricultura, vol. LXXI(1), 2016, pp. 53-63.

[18] Knapowski T., Kozera W., Majcherczak E., Barczak B. Wpływ nawożenia azotem i cynkiem na skład chemiczny i plon białka ziarna pszenżyta jarego. (Effect of nitrogen and zinc fertilisation on chemical composition and protein yield of spring triticale grain). Fragmenta Agronomica, vol. 27(4), 2010, pp. 45-55. (In Polish).

[19] Scigalska B., Pisulewska E., Kołodziejczyk M. Zawartość makro- i mikroelementów w ziarnie odmian pszenżyta jarego. (Content of macro and microelements in grain of spring triticale cultivars). Folia Pomeranae Universitatis Technologiae Stetinensis, Agricultura, vol. 206 (82), 2000, pp. 287-292.(In Polish).

[20] Brzozowska I. Influence of herbicides and nitrogen application method on the content of macroelements in winter triticale grain. Pamiętnik. Puławski, vol. 142, 2006, pp. 9-17.(In Polish).

[21] Makarska E., Ciołek A., Kociuba W. Influence of parental forms on changes in the content of mineral elements in grain of new winter triticale hybrid strains. Journal of Elementology, vol. 15(1), 2010, pp. 131-140. 